Journal of Agriculture and Natural Resources (2018) 1(1): 62-75

ISSN: 2661-6270 (Print), ISSN: 2661-6289 (Online)

\title{
Research Article \\ Effect of climate change in paddy production and adaptation strategies in Tharu communities of Dang district, Nepal
}

\author{
${ }^{1}$ Pradip Raj Poudel, ${ }^{2}$ Narayan Raj Joshi and ${ }^{3}$ Shanta Pokhrel \\ ${ }^{1}$ Agriculture Trainer, Council for Technical Education and Vocational Training, Rural Training Center, \\ Simpani, Lamjung, Nepal \\ ${ }^{2}$ Narayan Raj Joshi, Professor, Agriculture and Forestry University, Rampur, Chitwan, Nepal \\ ${ }^{3}$ Student, Prithu Technical College, Lamahi Dang, Nepal \\ *Correspondence: pdp.rajpoudel@gmail .com; ORCID: https://orcid.org/0000-0002-4486-2302
}

Received: September 11; Accepted: December 07; Published: December 09.

(C) Copyright: Poudel et al. (2018).

(c) (1) (3) This work is licensed under a Creative Commons Attribution-NonCommercial 4.0
International License.

\begin{abstract}
A study on effects of climate change on rice (Oryza sativa) production in Tharu communities of Dang district of Nepal was conducted in 2018A.D to investigate the perception and major adaptation strategies followed by Tharu farmers. The study areas were selected purposively. Cross-sectional data was collected using a household survey of 120 households by applying simple random sampling technique with lottery method for sample selection. Primary data were collected using semi-structured and pretested interview schedule, focus group discussion and key informants interview whereas monthly and annual time series data on temperature and precipitation over 21years (1996-2016) were collected from Department of Hydrology and Meteorology, Kathmandu as secondary data. Descriptive statistics and trend analysis were used to analyze the data. The ratio of male and female was found to be equal with higher literacy rate at study area than district. Most of the farmers depended on agriculture only for their livelihood where there was large variation in land distribution. Farmers had better access to FM/radio for agricultural extension information sources. The study resulted that Tharu farmers of Dang perceived all parameters of climate. Temperature and rainfall were the most changing component of climate perceived by farmers. The trend analysis of temperature data of Dang over 21 years showed that maximum, minimum and average temperature were increasing at the rate of $0.031{ }^{\circ} \mathrm{C}, 0.021^{\circ} \mathrm{C}$ and $0.072^{\circ} \mathrm{C}$ per year respectively which supports the farmers perception whereas trend of rainfall was decreased with $7.56 \mathrm{~mm}$ per year. The yearly maximum rainfall amount was increased by $1.15 \mathrm{~mm}$. The production of local indigenous rice varieties were decreasing while hybrid and improved rice varieties were increasing. The district rice production trend was increasing which support the farmer's perception. The study revealed that there were climate change effects on paddy production and using various adaptation strategies to cope in Dang district.
\end{abstract}

Keywords: Climate change, paddy production, Tharu farmers, adaptation strategies

Correct citation: Poudel, P. R., Joshi, N. R., \& Pokhrel, S. (2018). Effect of climate change in paddy production and adaptation strategies in Tharu communities of Dang District, Nepal. Journal of Agriculture and Natural Resources, 1(1), 62-75. 
Journal of Agriculture and Natural Resources (2018) 1(1): 62-75

ISSN: 2661-6270 (Print), ISSN: 2661-6289 (Online)

\section{INTRODUCTION}

The term climate change was introduced by the World Meteorological Organization to encompass all forms of variations in the climate variability on time-scales of greater than 10 years, whether the cause was natural or anthropogenic. In later years when it was realized conclusively that human activities had the potential to drastically alter the climate (Mitchell, 2017).Climate change is considered the most critical global challenge of the century. It is predicted that global temperature will increase further by between $1.4^{\circ} \mathrm{C}$ and $5.8^{\circ} \mathrm{C}$ by $2100 \mathrm{AD}$ (IPCC, 2007). Climate change may affect agriculture and food security by altering the spatial and temporal distribution of rainfall and the availability of water, land, capital, biodiversity and terrestrial resources. The delay in monsoon season has also made thousands of hectares of farm land fallow and reduced production due to lack of water (Regmi \& Adhikari, 2007). A drought in the eastern region of Nepal decreased the rice production by 30 percent in 2006 and heavy flooding in the mid-Western and far-Western regions in 2006 and 2008 destroyed crops in many places (Malla, 2008).

Nepal is multi-lingual, multi-cultural and multi-ethnic country. Tharus are the most dominant ethnic group living in western terai region of Nepal. Tharu were subjected to an extreme form of socioeconomic exploitation through the kamaiya system. Dang lies in terai region of Nepal and is the origin of Tharu community and most of the Tharu people stayed as Kamaiya before a decade. Due to this, they are poor and vulnerable to the changing pattern of the climate. Tharus being inhabitants of Terai region are facing climatic stresses each year and they are adapting these changing climates with their traditional skills and experiences (Maharjan et al., 2011). In addition about 29 percent of total population in this district is occupied by Tharu community. There is evidence that these indigenous people will face the brunt of negative climate change effects and will fall even deeper into poverty and face further livelihood problems (Eriksen, \& O'brien, 2007). High humidity creates a favorable environment for the growth of fungal and bacterial diseases. In addition, some insects and pests become active and damage the crops (Gentle \& Maraseni, 2012). Indigenous people have learned through systems of knowledge, practices and beliefs to conserve, maintain and promote their resources. They have developed robust capability for resilience and have been recognized as a valuable source of information regarding natural processes and their dynamics. Nevertheless, indigenous peoples' observations, knowledge and practices, especially in developing countries such as Nepal, have been little researched. In Nepal, indigenous people are highly dependent on agriculture. Their communities are often small, localized and most vulnerable to climate change. Flood, windstorm, erratic precipitation, and heavy and unseasonal rain are the major challenges to the Tharu community and their livelihoods. Moreover, the Tharu suffer due to loss of agricultural production from increased incidents of diseases, pests and weeds (Devkota et al., 2011). It is often said that the snow cover area in Himalayas is decreasing and farmer growing wheat cannot get enough moisture due to delayed snowfall. So these scenarios are threatened to the Nepalese farming system which ultimately affects the food security (Maharjan \& Joshi, 2013). 
Journal of Agriculture and Natural Resources (2018) 1(1): 62-75

ISSN: 2661-6270 (Print), ISSN: 2661-6289 (Online)

\section{METHODOLOGY}

The study was conducted in Lamahi and Gadawa rural municipality of Dang district, Nepal. The study area was selected purposely based on maximum number of Tharu household cultivating rainy season rice. The total of 831 rainy season rice cultivating Tharu farmers of the study area were considered as target population. Out of 831 households, 120 farmers were selected randomly. Semi-structured interview schedule was prepared. The pre-tested semi-structured interview schedule was administered for household survey. The secondary data of temperature and rainfall from 1996 to 2016 of the study area was obtained from Department of Hydrology and Meteorology (DHM), Kathmandu whereas data of area and production of rice were obtained from District Agriculture Development Office (DADO), Dang. Socioeconomic and farm characteristics of the respondents like age, occupational pattern, size of land holding, distribution of economically active population were described by using simple descriptive statistics like frequency count, percentage, mean, standard deviation. Changes in the trend of rainfall, temperature, area and production of paddy were analyzed by estimating the trend line.

\section{RESULTS AND DISCUSSION}

\section{Socio-economic and demographic characteristics of the respondents}

The socio-economic characteristics of the respondents include population distribution, gender distribution, education, occupation, land utilization pattern, and major source of livelihood. These characteristics are described below.

\section{Population distribution on sample household by sex}

The total population of sampled household was found to be 603, 306 and 297 from Lamahi and Gadawa respectively. Out of which 48.24 percent were male and 51.76 percent were female shown in table 1. Average family size of respondent's area was found to be 5 which is near about the census data 2011 AD. Average family size of study area was found to be 5 which were near about 4.75, average family size of dang district (CBS, 2016).

Table 1: Distribution of population on sampled household by sex

\begin{tabular}{lccc}
\hline Sex & Lamahi & Gadawa & Total \\
\hline Male & $157(51.7)$ & $137(46.13)$ & $294(48.24)$ \\
Female & $193(49.5)$ & $191(47.5)$ & $309(51.76)$ \\
\hline & $306(100)$ & $297(100)$ & $603(100)$ \\
\hline
\end{tabular}

Note: Figures in the parentheses indicate percent

(Source: Field Survey, 2018) 
Journal of Agriculture and Natural Resources (2018) 1(1): 62-75

ISSN: 2661-6270 (Print), ISSN: 2661-6289 (Online)

\section{Economically active family members}

Age of family members was categorized in to three classes, young (less than 15 years), adult (1559 years) and old (more than 59 years) and the distribution in the family members presented in Table 2.

Table 2: Distribution of economically active family members in sampled household

\begin{tabular}{lccc}
\hline Age group (Years) & Lamahi & Gadawa & Total \\
\hline Young & $86(28.1)$ & $94(31.7)$ & $180(29.9)$ \\
Adult & $180(58.8)$ & $167(56.2)$ & $347(57.5)$ \\
Old & $40(13.1)$ & $34(12.1)$ & $76(12.6)$ \\
\hline Total & $306(100)$ & $297(100)$ & $603(100)$ \\
\hline
\end{tabular}

Note: Figures in the parentheses indicate percent

(Source: Field Survey, 2018)

The economically active member is that part of manpower which actually engages or attempts to engage in the production of goods and services. The number of economically active population is interlinked with the income earning opportunities. The percentage of economically active member in study area (57.5 percent) was higher than national figure (57 percent) (CBS, 2016).

\section{Sample respondents by sex}

Out of 120 respondents 50.80 percent were male and 49.20 percent were female. This shows that there was equal ratio in male and female respondents.

Table 3: Distribution of sampled respondents by sex

\begin{tabular}{lccc}
\hline Sex & Lamahi & Gadawa & Total \\
\hline Male & $29(48.33)$ & $32(53.33)$ & $61(50.80)$ \\
Female & $31(51.67)$ & $28(46.67)$ & $59(49.20)$ \\
\hline Total & $60(100)$ & $60(100)$ & $120(100)$ \\
\hline
\end{tabular}

Note: Figures in the parentheses indicate percent

(Source: Field Survey, 2018)

Female farmers have been found to be more likely to adopt natural resource management and conservation practices (Bayard et al., 2007). However, some studies found that household gender was not a significant factor influencing farmers' decisions to adopt conservation measures (Bekele \& Drake, 2003). So, that female- and male-headed household differs in their ability to adapt to climate change because of major differences between them in terms of access to assets, education and other critical services such as credit, technology and input supply.

\section{Educational status of the respondents}

Education level of the respondents was calculated as number of years that respondent went to formal school. The descriptive statistics of the number of education years of the respondents is shown in Table 4. Results showed the literacy rate of the respondents was 69.17 percent which is higher than district data that is 62.80 percent. 
Journal of Agriculture and Natural Resources (2018) 1(1): 62-75

ISSN: 2661-6270 (Print), ISSN: 2661-6289 (Online)

Table 4: Distribution of respondents according to level of education

\begin{tabular}{lccc}
\hline Education level & Lamahi & Gaadawa & Total \\
\hline Illiterate & $12(20.00)$ & $25(46.67)$ & $37(30.83)$ \\
Primary level (up to 5 class) & $16(26.67)$ & $9(15.00)$ & $25(20.83)$ \\
Secondary level (up to 10 class) & $21(35.00)$ & $15(25.00)$ & $36(30.00)$ \\
College level or more & $11(18.33)$ & $11(18.33)$ & $22(18.34)$ \\
\hline Total & $60(100)$ & $60(100)$ & $120(100)$ \\
\hline Note: Figures in the parentheses indicate percent & & (Source: Field Survey, 2018)
\end{tabular}

\section{Occupation of respondent}

The occupational pattern of respondents in the study area were divided into four categories namely farming only, farming and job, farming and business and, farming and wage labor and the distribution of the respondents were accordingly presented in table 5.

The occupational pattern of household head showed that 70 percent of the household heads were engaged in farming only followed by farming and job (13.33 percent), farming and wage labor (10 percent), farming and business (6.67 percent). More farmer of Gadawa rural municipality were engaged in wage labour along with farming than Lamahi municipality.

Table 5: Distribution of respondents according to their occupation

\begin{tabular}{lccc}
\hline Variables & Lamahi & Gadawa & Total \\
\hline Farming & $45(75.00)$ & $39(65.00)$ & $84(70.00)$ \\
Farming and Job & $8(13.33)$ & $8(13.33)$ & $16(13.33)$ \\
Farming and Business & $5(8.33)$ & $3(5.00)$ & $8(6.67)$ \\
Farming and Wage labor & $2(3.34)$ & $10(16.67)$ & $12(10)$ \\
\hline Total & $60(1000$ & $60(100)$ & $120(100)$ \\
\hline
\end{tabular}

Note: Figures in parentheses indicate percent

(Source: Field Survey, 2018)

\section{Land holding of respondent's household}

Land is the important component of any farming system. Land ownership provides the major source of income and important natural assets as well. Study showed that all most all sampled household possessed the land ownership. According to land size, farmers were categories to small, medium and large farmers having land area less than 0.5 ha, 0.5 to 1 ha and more than 1 ha respectively. The study revealed that there was large variation in land distribution and large numbers of households (41.70 percent) having small pieces of land holdings.

Table 6: Distribution of respondents according to their land holding

\begin{tabular}{|c|c|c|c|c|c|}
\hline \multirow{2}{*}{ Category of land holding } & & \multicolumn{3}{|c|}{ No of respondents } & \\
\hline & & Lamahi & Gadawa & Total & \\
\hline Small(less than 0.5 ha) & & $32(53.3)$ & $18(30)$ & $50(41.7)$ & \\
\hline Medium (0.5- 1.0 ha) & & $18(30)$ & $22(36.7)$ & $40(33.3)$ & \\
\hline Large(more than 1.0 ha) & & $10(16.7)$ & $20(33.3)$ & $30(25)$ & \\
\hline \multirow[t]{2}{*}{ Total } & & $60(100)$ & $60(100)$ & $120(100)$ & \\
\hline & $\mathrm{N}$ & Minimum & Maximum & Mean & Std. deviation \\
\hline Land holding of respondent (kattha) & 120 & 3.00 & 140.00 & 24.25 & 21.52 \\
\hline
\end{tabular}


Journal of Agriculture and Natural Resources (2018) 1(1): 62-75

ISSN: 2661-6270 (Print), ISSN: 2661-6289 (Online)

\section{Knowledge and source of information on climate change}

Out of the 120 respondents, 83.3 percent were aware about climate change. Among them, only 32.50 percent of farmers heard climate change frequently while 50.83 percent heard occasionally. Major source of information about climate change was neighbor/friends (47 percent), followed by mass media ( 45 percent) and teachers/trainer ( 8 percent).

Table 7: Respondents' knowledge and source of information on climate change

\begin{tabular}{|c|c|c|c|c|}
\hline & & \multicolumn{3}{|c|}{ Respondents number } \\
\hline & Categories & $\begin{array}{c}\text { Lamahi } \\
\mathrm{n}=60\end{array}$ & $\begin{array}{c}\text { Gadawa } \\
\mathrm{n}=60\end{array}$ & $\begin{array}{c}\text { Total } \\
\mathrm{N}=120\end{array}$ \\
\hline \multirow{4}{*}{ Have you heard climate change? } & Never & $7(11.67)$ & $13(21.67)$ & $20(16.67)$ \\
\hline & Occasionally & $30(50.00)$ & $31(51.66)$ & $61(50.83)$ \\
\hline & Frequently & $23(38.33)$ & $16(26.67)$ & $39(32.50)$ \\
\hline & & $\begin{array}{c}\text { Lamahi } \\
\mathrm{n}=53\end{array}$ & $\begin{array}{c}\text { Gadawa } \\
\mathrm{n}=47\end{array}$ & $\begin{array}{c}\text { Total } \\
\mathrm{N}=100\end{array}$ \\
\hline \multirow[t]{2}{*}{$\begin{array}{l}\text { From whom you heard the climate } \\
\text { change? }\end{array}$} & $\begin{array}{c}\text { teacher/trainer } \\
\text { neighbor/friends } \\
\text { mass media }\end{array}$ & $\begin{array}{c}7(13.20) \\
21(39.60) \\
25(47.20)\end{array}$ & $\begin{array}{c}1(2.10) \\
26(55.30) \\
20(42.60)\end{array}$ & $\begin{array}{c}8(8.00) \\
47(47.00) \\
45(45.00)\end{array}$ \\
\hline & & $\begin{array}{c}\text { Lamahi } \\
n=60\end{array}$ & $\begin{array}{c}\text { Gadawa } \\
\mathrm{n}=60\end{array}$ & $\begin{array}{c}\text { Total } \\
\mathrm{N}=120\end{array}$ \\
\hline $\begin{array}{l}\text { Which components of climate have you } \\
\text { felt changing? }\end{array}$ & $\begin{array}{l}\text { Temperature } \\
\text { Rainfall }\end{array}$ & $\begin{array}{l}32(53.33) \\
28(46.67)\end{array}$ & $\begin{array}{l}36(60.00) \\
24(40.00)\end{array}$ & $\begin{array}{l}68(56.67) \\
52(43.33)\end{array}$ \\
\hline
\end{tabular}

\section{Farmers' perception about climate change}

Farmer's response towards climate parameter were quantified in score by using a 1 to 5 Likert scale (strongly disagree -2 , disagree -1 , neutral 0 , agree +1 , strongly agree +2 ) and later on scale is merged in 3 scale value (-1 disagree, 0 agree, and 1 agree) and ranked accordingly. From the perception of farmer's, it is found that summer temperature was most changing parameters which gain the highest index score and followed by rainfall timing. Similarly rainfall timing, annual temperature, rainfall intensity, rainfall pattern, winter pattern are found to be changing and ranked. Among the asked parameters hailstorm events perceived as the least changing parameter shown in Table 8.

Change in weather parameters is important factor that determine the farmers' perception about climate change. Respondent were asked whether they had experienced any deviation in the weather parameters like rainfall, temperature, drought, hot waves, and cold waves. Majority of the respondents had experienced the change in the climatic parameters shown in Table 8. 
Journal of Agriculture and Natural Resources (2018) 1(1): 62-75

ISSN: 2661-6270 (Print), ISSN: 2661-6289 (Online)

Table 8: Distribution of respondents according to their perception about climate change

\begin{tabular}{lcccccc}
\hline \multirow{2}{*}{ Climate parameters } & $\mathrm{D}$ & $\mathrm{U}$ & $\mathrm{A}$ & Total & \multirow{2}{*}{ Index value } & Rank \\
\cline { 2 - 5 } & $\mathrm{N}_{1}$ & $\mathrm{~N}_{2}$ & $\mathrm{~N}_{3}$ & $\mathrm{~N}$ & & \\
\hline Rainfall pattern is changing & 8 & 21 & 91 & 120 & 0.69 & IV \\
Rainfall timing is changing & 4 & 16 & 100 & 120 & 0.81 & II \\
Rainfall amount is changing & 26 & 12 & 82 & 120 & 0.48 & VI \\
Rainfall intensity is changing & 11 & 8 & 101 & 120 & 0.75 & III \\
Summer temperature is changing & 4 & 8 & 108 & 120 & 0.84 & I \\
Winter temperature is changing & 6 & 18 & 96 & 120 & 0.75 & III \\
Annual temperature is changing & 16 & 22 & 82 & 120 & 0.54 & V \\
Hot waves is changing & 32 & 21 & 67 & 120 & 0.27 & VIII \\
Cold waves is changing & 23 & 26 & 71 & 120 & 0.39 & VII \\
Hailstorm events is changing & 28 & 41 & 51 & 120 & 0.18 & X \\
Thunderstorm and lightening events are changing & 38 & 16 & 66 & 120 & 0.24 & IX \\
Wind velocity is changing & 31 & 38 & 59 & 120 & 0.24 & IX \\
\hline
\end{tabular}

$D=$ disagree, $U=$ undecided, $A=$ agree,

(Source: Field Survey, 2018)

Respondent of study area perceived that climatic parameters were changed hazardously. Among 120 respondent 91 respondents gave positive response towards the changing rainfall pattern, 100 respondents gave positive response to timing of rainfall changed, 82 respondents perceived positively to the rainfall amount changed and 101 respondent perceived that intensity of rainfall is changing. Table 9 revealed that that 84.17 percent of farmers perceived summer temperature was increasing and 56.67 percent perceived winter temperature was decreasing. Similarly most of the farmers (79.17 percent) perceived frequency of rainfall was decreasing while 49.17 percent farmers perceived intensity of rainfall was decreasing and 40.83 percent farmer perceived intensity of rainfall was increasing. Respondent of study area perceived that climatic parameters like temperature, hot waves, cold waves, drought, hailstorm, lightening were changed hazardously. Similar type of perception was studied in western terai region of Nepal (Devkota, 2014).

Table 9: Perception of farmers regarding temperature and rainfall

\begin{tabular}{llccc}
\hline & & $\begin{array}{c}\text { Total } \\
(\mathrm{N}=120)\end{array}$ & $\begin{array}{c}\text { Lamahi } \\
(\mathrm{n}=60)\end{array}$ & $\begin{array}{c}\text { Gadawa } \\
(\mathrm{n}=60)\end{array}$ \\
\hline \multirow{3}{*}{ Summer temperature } & Increasing & $101(84.17)$ & $51(85.00)$ & $50(83.33)$ \\
& Decreasing & $5(4.17)$ & $1(1.67)$ & $4(6.67)$ \\
& Not noticed & $14(11.66)$ & $8(13.33)$ & $6(10.00)$ \\
\hline \multirow{3}{*}{ Winter temperature } & Increasing & $42(35.00)$ & $19(31.67)$ & $23(38.33)$ \\
& Decreasing & $68(56.67)$ & $37(61.67)$ & $31(51.67)$ \\
& Not noticed & $10(8.33)$ & $4(6.66)$ & $6(10.00)$ \\
\hline Frequency of rainfall & Increasing & $6(5.00)$ & $4(6.67)$ & $2(3.33)$ \\
& Decreasing & $95(79.17)$ & $51(85.00)$ & $44(73.33)$ \\
& Not noticed & $19(15.83)$ & $5(8.33)$ & $14(23.34)$ \\
\hline Intensity of rainfall & Increasing & $49(40.83)$ & $32(53.33)$ & $17(28.33)$ \\
& Decreasing & $59(49.17)$ & $22(36.67)$ & $37(61.67)$ \\
& Not noticed & $12(10.00)$ & $6(10.00)$ & $6(10.00)$ \\
\hline
\end{tabular}

Notes: Figures in parentheses indicate percentage.

(Source: Field Survey 2018) 
Journal of Agriculture and Natural Resources (2018) 1(1): 62-75

ISSN: 2661-6270 (Print), ISSN: 2661-6289 (Online)

Respondents experiences in rice cultivation practices comparing before five years and now

Table 10: Respondents experiences in rice cultivation practices comparing before five years and now

\begin{tabular}{|c|c|c|c|c|}
\hline \multicolumn{2}{|c|}{ Comparing before 5 years and now } & $\begin{array}{c}\text { Total } \\
(\mathrm{N}=120)\end{array}$ & $\begin{array}{c}\text { Lamahi } \\
(\mathrm{n}=60)\end{array}$ & $\begin{array}{c}\text { Gadawa } \\
(\mathrm{n}=60)\end{array}$ \\
\hline \multirow{2}{*}{ Pest and disease } & Evidence of pest and disease & $81(67.5)$ & $46(76.7)$ & $35(58.3)$ \\
\hline & Higher in number & $39(32.5)$ & $14(23.3)$ & 25(41.7) \\
\hline \multirow{3}{*}{ Transplanting time } & Earlier & $7(5.8)$ & $0(0.0)$ & $7(11.7)$ \\
\hline & Late & $56(46.7)$ & $33(55.0)$ & $23(38.3)$ \\
\hline & Normal time & $57(47.5)$ & $27(45.0)$ & $30(50.0)$ \\
\hline \multirow{3}{*}{ Harvesting time } & Earlier & $6(5.0)$ & $0(0.0)$ & $6(10.0)$ \\
\hline & Late & $53(44.2)$ & $33(55.0)$ & $20(33.3)$ \\
\hline & Normal time & $61(50.8)$ & $27(45.0)$ & $34(56.7)$ \\
\hline \multirow{3}{*}{ Yield of rice } & High & $86(71.7)$ & $53(88.3)$ & $33(55.0)$ \\
\hline & Low & $24(20.0)$ & $5(8.3)$ & $19(31.7)$ \\
\hline & Normal & $10(8.3)$ & $2(3.4)$ & $8(13.3)$ \\
\hline \multirow{3}{*}{ Weed infestation } & lower & $6(5.0)$ & $1(1.7)$ & $5(8.4)$ \\
\hline & Higher & $57(47.5)$ & $31(51.7)$ & $26(43.3)$ \\
\hline & Normal & $57(47.5)$ & $28(46.6)$ & $29(48.3)$ \\
\hline \multirow{3}{*}{ Occurrence of Hailstone } & Less & $60(50.0)$ & $36(60.0)$ & $24(40.0)$ \\
\hline & Normal & $60(50.0)$ & $24(40.0)$ & $36(60.0)$ \\
\hline & More & $75(62.5)$ & $37(61.7)$ & $38(63.3)$ \\
\hline \multirow{2}{*}{ Drought } & Less & $5(4.2)$ & $0(0.0)$ & $5(8.4)$ \\
\hline & Normal & $40(33.3)$ & $23(38.3)$ & $17(28.3)$ \\
\hline
\end{tabular}

Notes: Figures in parentheses indicate percentage

(Source: Field Survey, 2018)

Table 10 shows various rice cultivation practices and farmer's experience on these can also be used to evaluate both climatic and non-climatic factors affecting production and productivity of rice. Comparing the experiences of farmers 5 years before and now about the Pest and disease appearance; rice transplanting and harvesting time; hailstone prevalence; drought duration; weed infestation and yield variation give the scenario of effect of climatic factors. Majority of respondents had experienced late transplanting and late harvesting time than before. About 71.7 percent of respondent got more yield than before; this may be due to quality seed and better cultural practices. Table 14 revealed that 81.66 percent farmers perceived as local varieties of paddy production was decreasing, 66.67 percent farmers perceived improved variety paddy production was increasing and 78.33 percent farmers perceived hybrid variety paddy production was increasing shown in Table 11.

Table 11: Distribution of Farmers according to their perception on rice production

\begin{tabular}{lcccc}
\hline $\begin{array}{l}\text { Rice production before } 5 \\
\text { years and now }\end{array}$ & Increasing & Constant & Decreasing & Total \\
\hline Local & $10(8.33)$ & $12(10.00)$ & $98(81.66)$ & $120(100)$ \\
Improved & $80(66.67)$ & $32(26.67)$ & $8(6.67)$ & $120(100)$ \\
Hybrid & $94(78.33)$ & $21(17.50)$ & $5(4.17)$ & $120(100)$ \\
\hline
\end{tabular}

Notes: Figures in parentheses indicate percentage

(Source: Field Survey, 2018) 
Journal of Agriculture and Natural Resources (2018) 1(1): 62-75

ISSN: 2661-6270 (Print), ISSN: 2661-6289 (Online)

\section{Trend in climatic data}

\section{Trend of temperature at Dang district}

While analyzing the trend of temperature of last 21 years of the Dang, Ghorahi station, and the trend showed that maximum temperature, minimum temperature, and average temperature were increased by $0.0316^{\circ} \mathrm{C}, 0.0726^{\circ} \mathrm{C}$ and $0.0212^{\circ} \mathrm{C}$ per year respectively. The trend analysis strongly supported the farmer perception that temperature was increasing. All Nepal maximum temperature trend was positive and annual temperature trend was $0.056^{\circ} \mathrm{C}$ per year (DHM, 2017). This study showed that higher annual positive trend in Dang average maximum temperature than minimum temperature. This pattern was consistent with the previous studies of trend of Nepal (PAN, 2009, DHM, 2017).

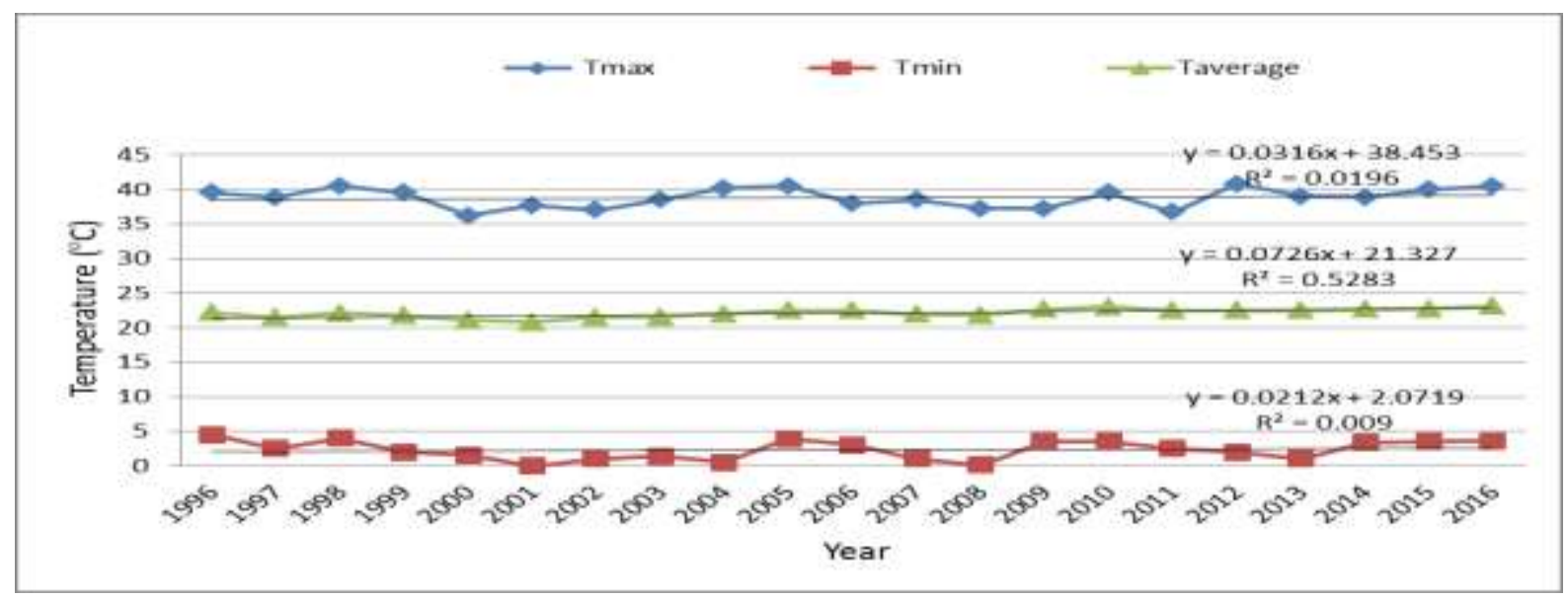

Figure 1: Trend of temperature $\left({ }^{\circ} \mathrm{C}\right)$ at Dang $(1996-2016)$

\section{Trend of rainfall at Dang district}

The analysis of the rainfall of last 21 years of the Dang, Ghorahi station showed that there was irregular pattern of rainfall. The trend showed that annual total rainfall was decreased with $7.56 \mathrm{~mm}$ per year. The yearly maximum rainfall amount was increased by $1.15 \mathrm{~mm}$. It showed that amount of precipitation was decreasing while the intensity of precipitation was increasing because of increase in annual maximum rainfall. 
Journal of Agriculture and Natural Resources (2018) 1(1): 62-75 ISSN: 2661-6270 (Print), ISSN: 2661-6289 (Online)

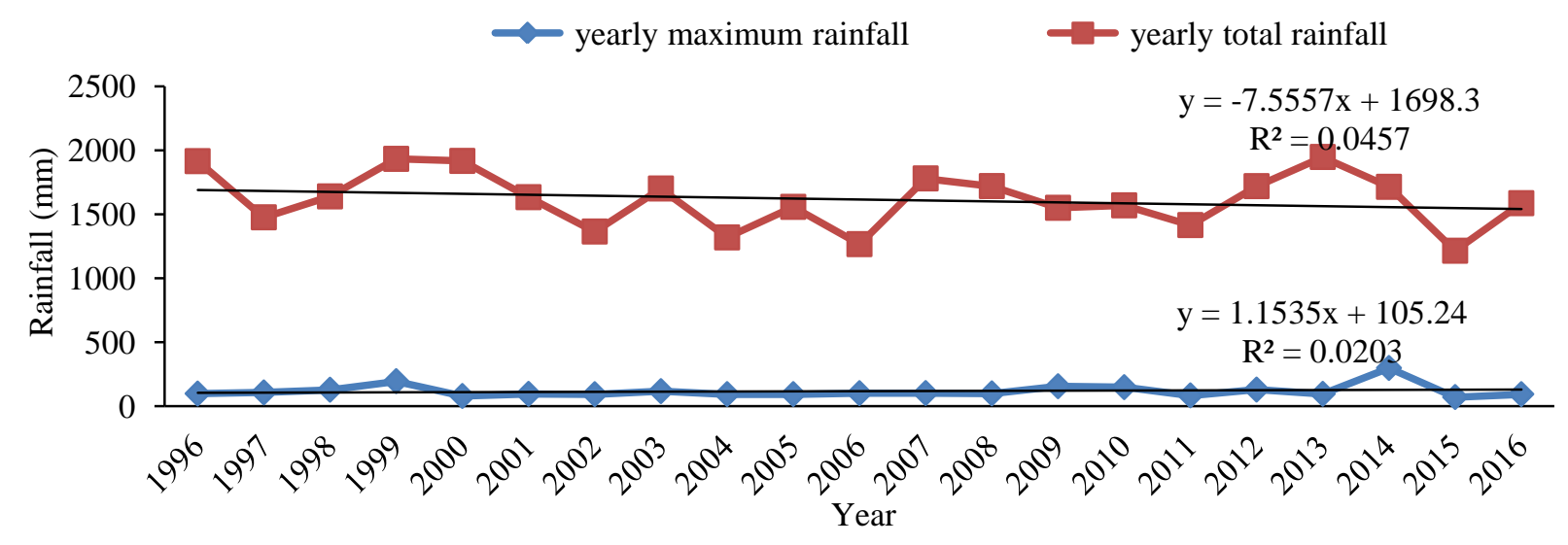

Figure 2: Trend of rainfall (mm) at Dang (1996-2016)

Trend of production and area of rice in Dang District

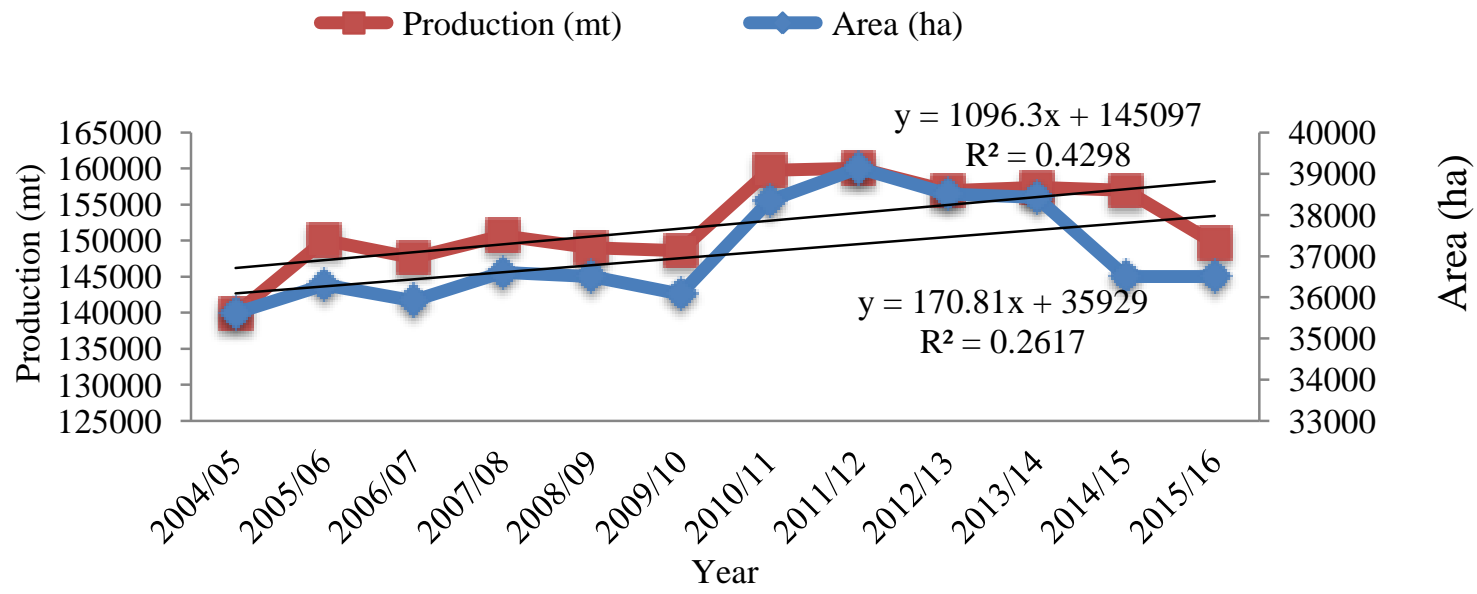

Figure 3: Trend of production and area of rice in Dang (2004-2016)

While analyzing the data on area and production of rice of 12 years data from DADO, dang, the trend showed that both area under rice cultivation and production of rice was increasing. The area under rice cultivation and rice production were increasing with the rate of 170.81 ha and $1096.30 \mathrm{mt}$ per year respectively in Dang District. 
Journal of Agriculture and Natural Resources (2018) 1(1): 62-75

ISSN: 2661-6270 (Print), ISSN: 2661-6289 (Online)

Adaptation strategies of farmers to cope climate change in rice cultivation

Table 12: Distribution of respondents according to adaptation strategies on climate change in rice cultivation

\begin{tabular}{|c|c|c|c|c|c|}
\hline \multicolumn{3}{|l|}{ Strategies } & $\begin{array}{c}\text { Total } \\
(\mathrm{N}=120)\end{array}$ & $\begin{array}{c}\text { Lamahi } \\
(\mathrm{n}=60)\end{array}$ & $\begin{array}{c}\text { Gadawa } \\
(\mathrm{n}=60)\end{array}$ \\
\hline \multirow{2}{*}{\multicolumn{2}{|c|}{ Adopt any climate change adaptation measures }} & Yes & $105(87.5)$ & $45(75.0)$ & $60(100.0)$ \\
\hline & & No & $15(12.5)$ & $15(25.0)$ & $0(0.0)$ \\
\hline \multicolumn{3}{|l|}{ If yes } & $\begin{array}{c}\text { Total } \\
(\mathrm{N}=105)\end{array}$ & $\begin{array}{l}\text { Lamahi } \\
(n=45)\end{array}$ & $\begin{array}{c}\text { Gadawa } \\
(\mathrm{n}=60)\end{array}$ \\
\hline \multirow{2}{*}{ Change crop varieties } & & Yes & $84(80.0)$ & $34(75.6)$ & $50(83.3)$ \\
\hline & & NO & $21(20.0)$ & $11(24.4)$ & $10(16.7)$ \\
\hline \multirow[t]{4}{*}{ If yes } & & & $68(81.0)$ & $31(91.2)$ & $37(74.0)$ \\
\hline & & & $82(97.6)$ & $34(100.0)$ & $48(96.0)$ \\
\hline & & & $10(11.9)$ & $8(23.5)$ & $2(4.0)$ \\
\hline & & & $24(28.6)$ & $4(11.8)$ & $20(40.0)$ \\
\hline \multirow{2}{*}{$\begin{array}{l}\text { Weed management } \\
\text { method you applying }\end{array}$} & \multicolumn{2}{|c|}{ Yes } & $105(100.0)$ & $45(100.0)$ & $60(100.0)$ \\
\hline & \multicolumn{2}{|c|}{ Manual } & $105(100.0)$ & $45(100.0)$ & $60(100.0)$ \\
\hline \multirow{2}{*}{ Pest management } & \multicolumn{2}{|c|}{ Yes } & $22(21.0)$ & $1(2.2)$ & $21(35.0)$ \\
\hline & \multicolumn{2}{|c|}{ No } & $83(79.0)$ & $44(97.8)$ & $39(65.0)$ \\
\hline Method you applying & \multicolumn{2}{|c|}{ Chemical } & $22(100.0)$ & $1(100.0)$ & $21(100.0)$ \\
\hline \multirow{2}{*}{ Fertilizer management } & \multirow{2}{*}{\multicolumn{2}{|c|}{$\begin{array}{l}\text { Yes } \\
\text { No }\end{array}$}} & 104(99.0) & $45(100.0)$ & $59(98.3)$ \\
\hline & & & $1(1.0)$ & $0(0.0)$ & $1(1.7)$ \\
\hline \multirow{3}{*}{ Type of fertilizers } & \multicolumn{2}{|c|}{ FYM } & $54(52.0)$ & $27(60.0)$ & $36(61.0)$ \\
\hline & \multirow{2}{*}{\multicolumn{2}{|c|}{$\begin{array}{l}\text { Compost } \\
\text { Chemical }\end{array}$}} & $38(36.5)$ & $17(37.8)$ & $21(35.60$ \\
\hline & & & $104(100)$ & $45(100)$ & $59(100)$ \\
\hline \multirow{2}{*}{ Irrigation management } & \multicolumn{2}{|c|}{ Yes } & $62(59.0)$ & $31(68.9)$ & $31(51.7)$ \\
\hline & \multicolumn{2}{|c|}{ No } & $43(41.0)$ & $14(31.1)$ & $29(48.3)$ \\
\hline \multirow{2}{*}{ Changing planting pattern } & \multicolumn{2}{|c|}{ Yes } & $45(42.9)$ & $29(64.4)$ & $16(26.7)$ \\
\hline & \multicolumn{2}{|c|}{ No } & $60(57.1)$ & $16(35.6)$ & $44(73.3)$ \\
\hline \multirow{2}{*}{ If yes, what you do } & \multicolumn{2}{|c|}{ late sowing } & $42(93.3)$ & $29(100.0)$ & $13(81.2)$ \\
\hline & \multicolumn{2}{|c|}{ early sowing } & $3(6.7)$ & $0(0.0)$ & $3(18.8)$ \\
\hline \multirow{2}{*}{ Green manuring } & \multirow{2}{*}{\multicolumn{2}{|c|}{$\begin{array}{l}\text { Yes } \\
\text { No }\end{array}$}} & $12(11.4)$ & $0(0.0)$ & $12(20.0)$ \\
\hline & & & $93(86.6)$ & $45(100.0)$ & $48(80.0)$ \\
\hline
\end{tabular}

Notes: Figures in parentheses indicate percentage.

(Source: Field Survey 2018)

Table 12 revealed that 87.5 percent of respondents' farmers used the adaptation strategies to changing climate. Majority of the Tharu farmers changed the crop varieties (80 percent) either hybrid (81 percent among variety change), or improve variety (97.6 percent among the variety change). Higher number of farmers used improved variety followed by hybrid, flood resistant and drought tolerant. Most of the farmers used the chemical fertilizer (99 Percent) for the nutrient management in rice cultivation along with the FYM and compost. 62 percent of farmers applied the irrigation management strategy shown in Table 12. 
Journal of Agriculture and Natural Resources (2018) 1(1): 62-75

ISSN: 2661-6270 (Print), ISSN: 2661-6289 (Online)

\section{CONCLUSION}

The world has been facing a new era of climate change and the effects of climate change are already being felt everywhere, particularly in the developing countries. The local knowledge systems and agricultural practices and techniques adopted by local people remain the dominant form of coping mechanisms to climate change.

This study was carried out to assess the Tharu farmers' perception and their adaptation strategies to climate change in Dang district of Nepal. The ratio of male and female was found in equal proportion in the study area. Education status of the people was higher than the district average literacy rate. Most of the farmers depended on agriculture only for their livelihood and had large variation in land distribution. Tharu farmers of Dang perceived that all parameters of climate like temperature, rainfall, hot waves, cold waves, hailstorm, thunderstorm, wind velocity were changed. Farmers perceived that temperature and rainfall were the most changing component of climate. The trend of temperature data of over 21 years (1996-2016) showed that maximum, minimum and average temperature were increasing at the rate of $0.031^{\circ} \mathrm{C}, 0.021^{\circ} \mathrm{C}$ and $0.072^{\circ} \mathrm{C}$ per year respectively in Dang. This showed that the trend was in the line with farmers' perception. Similarly, rainfall of last 21 years of the Dang, Ghorahi station showed that there was irregular pattern of rainfall. The trend showed that annual total rainfall was decreased with $7.56 \mathrm{~mm}$ per year. The yearly maximum rainfall amount was increased by $1.15 \mathrm{~mm}$. It showed that amount of precipitation was decreasing while the intensity of precipitation was increasing.

Most of the farmers replaced their previously used local varieties with either hybrid or improved. Manual weed management practice was used by the farmers and none of the farmers used the herbicidal weed management practice. The effect of climate change in rice production was seen. The production of local indigenous rice variety was decreasing, weed infestation and disease infestation on rice was also increasing in comparison to the past. Farmers perceived that the production of improved and hybrid variety rice was increasing. The trend of rice production in Dang district was increasing which supports the perception of Tharu farmer's about rice production in study area. Farmers used the different adaptation strategies to cope with the changing climate.

\section{ACKNOWLEDGEMENT}

This research has been granted by the Clean Energy Nepal (CEN). The authors therefore acknowledge CEN and the whole CEN team for providing me with the grant and cooperation. Also, they would like to heartily acknowledge to Shankar Prasad Sharma, program officer at CEN for their support and cooperation. 
Journal of Agriculture and Natural Resources (2018) 1(1): 62-75

ISSN: 2661-6270 (Print), ISSN: 2661-6289 (Online)

\section{Authors Contribution}

P.R.P. design and performed research analyzed data and wrote the paper; N.R. Joshi developed the methodology; and S.P. wrote the manuscript in consultation with P.R.P. P.R.P revised the article for the final approval of the version to be published.

\section{Conflicts of Interest}

The authors declare that there is no conflict of interest regarding the publication of this paper.

\section{REFERENCES}

Baidya, S. K., \& Karmacharya, J. (2010)). Observed and future climate change in Nepal. Proceeding of climate workshop held at Kathmandu, December 19-21 (pp. 22-23). Kathmandu.

Bayard, B., Jolly, C. M., \& Shannon, D. A. (2007). The economics of adoption and management of alley cropping in Haiti. Journal of Environmental Management, 84, 62-70.

Bekele, W., \& Drake, L. (2003). Soil and water conservation decision behavior of subsistence farmers in the Eastern Highlands of Ethiopia: a case study of the Hunde-Lafto area. Ecological Economics, 46, 437-451.

CBS. (2016). National population and housing census 2011 (Vol. 2). Government of Nepal, National planning commission secretariat. Central bureau of statistics. Kathmandu, Nepal.

Devkota, R. P. (2014). Climate change: Trends and People's Perception in Nepal. Journal of Environmental Protection, 5, 255-265. Retrieved May 1, 2018 from http://dx.doi.org/10.4236/jep.2014.54029

Devkota, R. P., Bajracharya, B., Maraseni, T. N., Cockfield, G., \& Upadhyay, B. P. (2011). The perception of Nepal's Tharu community in regard to climate change and its impacts on their livelihoods. International Journal of Environmental Studies, 68(6), 937-946.

DHM (2017) Study of Climate and climatic variation over Nepal. Department of Hydrology and Meteorology, Ministry of Population and Environment, Nepal

Di Falco, S., Veronesi, M., \& Yesuf, M. (2011). Does adaptation to climate change provide food security? A micro-perspective from Ethiopia. American Journal of Agricultural Economics, 93(3), 829-846.

Eriksen, S. H., \& O'brien, K. (2007). Vulnerability, poverty and the need for sustainable adaptation measures. Climate policy, 7(4), 337-352.

Gentle, P., \& Maraseni, T. N. (2012). Climate change, poverty and livelihoods: adaptation practices by rural mountain communities in Nepal. Environmental science \& policy, 21, 24-34.

IPCC. (2007). Summary for policy makers. In M. L. Parry, O. F. Canziani, J. P. Palutikof, P. J. Linden, \& C. E. Hanson (Ed.), Climate change 2007: Impacts, Adaptation and Vulnerability. Contribution of Working Group II to the Fourth Assessment of the 
Journal of Agriculture and Natural Resources (2018) 1(1): 62-75

ISSN: 2661-6270 (Print), ISSN: 2661-6289 (Online)

Intergovernmental Panel on Climate Change. Cambridge University Press, Cambridge, U.K.

Maharjan, K. L., \& Joshi, N. P. (2013). Effect of climate variables on yield of major food-crops in Nepal: A time-series analysis. In Climate Change, Agriculture and Rural Livelihoods in Developing Countries (pp. 127-137). Springer, Tokyo.

Maharjan, S. K., Sigdel, E. R., Sthapit, B. R., \& Regmi, B. R. (2011). Tharu community's perception on climate changes and their adaptive initiations to withstand its impacts in Western Terai of Nepal.

Malla, G. (2008). Climate change and its impact on Nepalese agriculture. The Journal of Agricultural and Environment, 9, 62-71.

Mitchell, G. R. (2017). Climate Change and Manufacturing. Procedia Manufacturing, 12, 298306.

PAN (2009) Temporal and Spatial Variability of Climate Change over Nepal (1976-2005). Practical Action Nepal, Kathmandu.

Regmi, B. R., \& Adhikari, A. (2007). Climate Risk and Vulnerability in Nepal.Country Case Study. Human Development Report 2007/2008 fighting climate change: Human solidarity in a divided world. Human Development Report Office Occasional Paper UNDP. 